\title{
CHANGE IN INHERITANCE IN ECHINOID HYBRIDS
}

\author{
By Sven Hörstadius \\ From the Plymouth Laboratory, and the Zootomical \\ Institute, Stockholm
}

(Text-figs. I-6)

In their classical study on experimental hybridization of the echinoids Echinus esculentus, E. acutus, and Psammechinus miliaris, Shearer, de Morgan $\&$ Fuchs (19I4) found that the hybrid larvae with $P$. miliaris eggs showed one type of inheritance in the years I909-II, but another in the year I9I2. The authors suggested that the peculiar temperature conditions of the sea water prevailing at Plymouth that year may have affected the germ cells of $P$. miliaris. In the summer of 1932, when studying heterosperm merogones of $P$. miliaris and Echinus esculentus at Plymouth (Hörstadius, I936), I also reared hybrids of $P$. miliaris $+\times E$. esculentus ô to metamorphosis. It was surprising to find that the larvae that year showed a third and fourth type of inheritance, an account of which will be presented in this paper, together with some remarks on possible causes of the different results of the crosses.

According to Shearer, de Morgan \& Fuchs (I9I2, I9I4) the plutei of $E$. esculentus possess, at a late larval stage, both anterior and posterior epaulettes, almost always a pedicellaria at the posterior end of the larva, but no green pigment masses. The larva has a body that is deeper than it is wide, the posterior pole being comparatively flattened.

As regards the fully-formed pluteus of $E$. acutus, the three authors state that it has a rather smaller body, with more slender and divergent arms than E. esculentus, but resembles the latter in all essential features, such as the development of the epaulettes and of the pedicellariae. They further point out that, owing to the similarity of the characters of this species and E. esculentus, their hybrids afford no information of value in the study of heredity.

The late larva of $P$. miliaris is described as being of a different general shape from that of E. esculentus and E. acutus. The width of the body is greater than its depth, and the posterior pole is more rounded. The arms are comparatively short. Unlike the two species mentioned above, the $P$. miliaris larva has no posterior epaulettes and no posterior pedicellaria, but four masses of green pigment are developed in the anterior epaulettes.

In the following table I have tried to collect all the results regarding the characters of green pigment, posterior epaulettes, and posterior pedicellaria. Absence of a character is marked o, presence + . As Shearer, de Morgan \& Fuchs call attention on several occasions to the fact that the posterior pedi- 
cellaria may occasionally be lacking in the pure larvae of $E$. esculentus and $E$. acutus, as well as in hybrids with eggs from these species, the + in the corresponding column is placed in parentheses. Usually when a character has not been expressly mentioned in the text of the papers quoted, it is represented by a note of interrogation, but if from the drawings or indirectly from the text, or from personal information, it has been possible to conclude something in regard to the presence or absence of the character in question, a + or $\circ$ has been put in the table, but followed by a mark of interrogation. The general shape of the body cannot be included as a character in the table, as too many deviations occur even within one species.

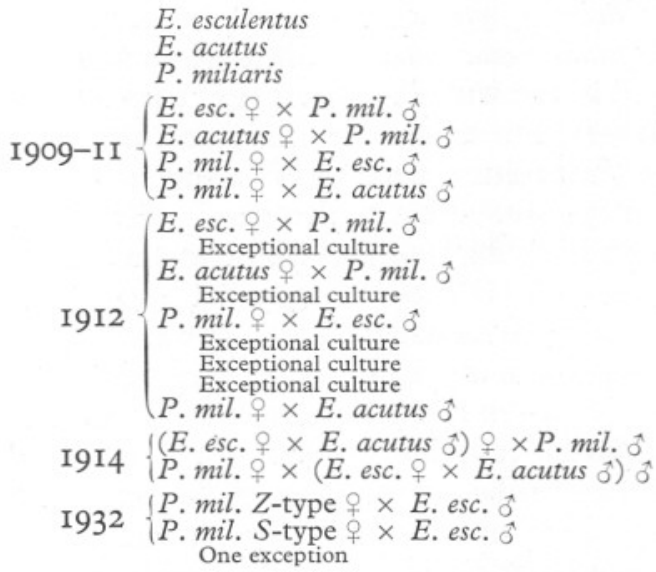

\begin{tabular}{|c|c|c|}
\hline $\begin{array}{l}\text { Green } \\
\text { pigment }\end{array}$ & $\begin{array}{c}\text { Posterior } \\
\text { epaulettes }\end{array}$ & $\begin{array}{l}\text { Posterior } \\
\text { pedicellaria }\end{array}$ \\
\hline 0 & + & $(+)$ \\
\hline$\circ$ & + & $(+)$ \\
\hline+ & 0 & 0 \\
\hline o & + & $(+)$ \\
\hline$\circ$ & + & $(+)$ \\
\hline+ & 0 & 0 \\
\hline+ & o & 0 \\
\hline$\circ$ & + & $(+)$ ? \\
\hline ○ & $\begin{array}{c}2 \text { or } 1 \text { or } 0 \\
+\end{array}$ & $(\stackrel{?}{+})$ ? \\
\hline$\circ$ & 2 or 1 or 0 & ? \\
\hline $\begin{array}{l}0 \\
+\end{array}$ & $\begin{array}{l}+ \\
0\end{array}$ & o? \\
\hline$\circ$ & 2 or 1 or 0 & $?$ \\
\hline \% & $\begin{array}{l}0 \\
+\end{array}$ & o? \\
\hline 0 & + & $?$ \\
\hline 0 & + & $?$ \\
\hline o & ० & o or + \\
\hline 0 & 0 & 0 \\
\hline ० & ○ & \\
\hline
\end{tabular}

During the years I909-II Shearer, de Morgan \& Fuchs (I9II, I9I2, I9I4) found that the inheritance in the hybrids was invariably maternal, the larvae in reciprocal crosses thus being different. As seen from the table, the hybrids E. esc. $+\times P$. mil. ${ }^{t}$ had no green pigment, but possessed posterior epaulettes and, most of them, the posterior pedicellaria also. In these respects they thus resembled the pure E. esculentus and E. acutus plutei. The shape of the body, however, was not so deep and flattened at the aboral pole as that of E. esculentus, nor so wide as that of $P$. miliaris. The arms were also rather intermediate in form.

The hybrids $P$. mil. ㅇ $\times$ E. esc. ${ }^{\star}$, like the normal $P$. miliaris plutei, were characterized by the green pigment and the complete lack of posterior epaulettes and posterior pedicellaria. Occasionally a group of mesenchyme cells could be observed at the posterior pole of the larva, as if in an attempt to form a pedicellaria. The pluteus had not so wide a body as in pure P. miliaris, and the arms were longer, but the general appearance was similar to this species.

As seen from the table, crosses between $E$. acutus and $P$. miliaris gave exactly the same pattern as when $P$. miliaris was hybridized with $E$. esculentus. 
In the season of I9I2, also at Plymouth, the inheritance was different from that of previous years, the offspring of crosses with $P$. miliaris eggs being as a rule paternal, not maternal (Shearer, de Morgan \& Fuchs, I9I2, I9I4). As seen from the table (under I9I2), this gave a dominance of the E. esculentus characters over those of $P$. miliaris in both reciprocals of the cross. In general form the hybrids were of the E. esculentus type and most of them (a few exceptions will be dealt with below) had posterior epaulettes but had not developed any green pigment masses. The three authors do not refer to the posterior pedicellaria in their material from I912. It has been mentioned above that the inheritance of this pedicellaria follows that of the posterior epaulettes, but that it is not a very reliable feature, as it sometimes fails to make its appearance in pure E. esculentus larvae, and sometimes also in the hybrids E. esc. 우 $\times$ P. mil. of I909-II [( +$)$ in table]. Although the presence or absence of the

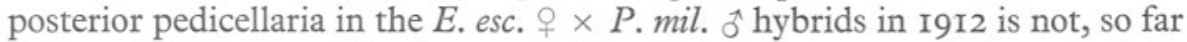
as I can find, indicated in the text of the papers, we can nevertheless conclude from the drawings (I9I2, text-fig. 4; I9I4, pl. 22 figs. 74-76, text-fig. II) that it was developed in some larvae, whereas in others it only seems to have been represented by a group of mesenchyme cells (I9I2, text-fig. 4; 19I4, pl. 22, fig. 73, text-fig. II). As to the frequency of the posterior pedicellaria in this cross, we know nothing. This character has therefore been marked $(+)$ ? in the table.

In the only drawing of a larva of the reciprocal cross, P. mil. ㅇ $\times$ E. esc. $\sigma^{t}$ I9I2 (I9I2, pl. I8, fig. 9; I9I4, pl. 22, fig. 77), there is no posterior pedicellaria present, only a group of mesenchyme cells, and no such pedicellaria has been expressly mentioned by Shearer, de Morgan \& Fuchs in any of their plutei with eggs of $P$. miliaris, neither in the pure $P$. miliaris larvae, nor in the other hybrids. On the other hand, it has to be mentioned that Shearer, de Morgan \& Fuchs, in the very last sentence of their paper of I9I4 (p. 344), write: "If our investigations at Plymouth had been confined to the summer of I9I2 alone, we should have arrived at the same conclusion as Loeb, King, \& Moore, that certain characters are definitely dominant, namely the posterior ciliated epaulettes and posterior pedicellariae, while the green pigment is recessive." Loeb, King \& Moore (I9IO) worked with other species and characters. As this statement has no support in the descriptions of the experiments, $P$. mil. + \& $\times E$.

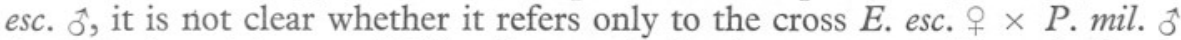
(and also here it is not valid for all cases, cf. the above paragraph) or whether it is intended to hold good also of the cross P. mil. ㅇ $\times$ E. esc. ot $^{\text {s. }}$

It is important to notice that when $P$. miliaris was crossed with $E$. acutus in the year I9I2 the same change in inheritance occurred as when it was crossed with $E$. esculentus. Thus $E$. acutus $q \times P$. mil. ô gave, as in I909-I I, no green pigment, but posterior epaulettes. As regards the posterior pedicellaria, nothing is mentioned in the text, but according to the drawings (I9I2, textfig. 3 ; I9I4, pl. 22, fig. 78, text-fig. I2) it seems to have developed. One exceptional culture will be mentioned below. Contrary to the results of I909- 
II the cross $P$. mil. $O \times$ E. acutus ${ }_{0}^{\wedge}$ inherited the E. acutus characters, having no green pigment, but possessing posterior epaulettes. To judge from pl. I8, fig. 7 , and text-fig. 3 (I9I2), as well as pl. 22, fig. 79, and text-fig. I2 (I9I4), no posterior pedicellaria was developed, but in some larvae a group of mesenchyme cells. The results were thus identical with those of the crosses $P$. miliaris and E. esculentus. Both with E. esculentus and E. acutus sperms added to $P$. miliaris eggs the inheritance was maternal in I909-II, paternal in I9I2.

In I9I2 the results were not as uniform as they had been in I909-II, as a few cultures showed exceptions (small type in table). While the majority of the hybrids E. esc. $+\times \times P$. mil. $\sigma^{t}$ were of the form of E. esculentus, the larvae in one exceptional culture had the general shape of $P$. miliaris, with a broad body, domed aboral end, and short arms. In this cross only four larvae exhibited the typical combination of two posterior epaulettes and lack of green pigment. In eight larvae only one of the posterior epaulettes developed, and in eleven larvae none. Exactly the same type of exception occurred in one of the crosses $E$. acutus + $\times P$. mil. $\hat{\delta}$, as all the larvae had the maternal absence of green pigment, but some had both posterior epaulettes, some had an epaulette on one side of the body only, and others had neither posterior epaulette.

In the crosses with $P$. miliaris 9 and $E$. esculentus ot two kinds of exceptions were observed in I9I2. In one culture ten plutei were of purely paternal form, having no green pigment but posterior epaulettes $(\mathrm{o}+)$, while twenty-five were of the purely maternal ( $P$. miliaris) type in general form and in developing green pigment masses but no posterior epaulettes ( +0 , small type in table). In another culture the larvae instead were-like those of all other cultures of this cross in 1912-of the E. esculentus type in general form, and they all also had the paternal absence of green pigment; but they differed among themselves with regard to the development of the posterior epaulettes. Eighteen had both posterior epaulettes, five developed only one posterior epaulette, and nine had none. These latter (no pigment, one or no posterior epaulette) thus showed the same combination of characters as the exceptions among E. esc. 우 $\times P$. mil. $\sigma^{*}$ and $E$. acutus o $\times P$. mil. $\sigma^{t}$ the same year (see above).

As seen from the figures (quoted above), the posterior pedicellaria was generally present in the exceptional larvae of the cross $E$. esc. $+9 \times P$. mil. $\sigma^{t}$ I9I2. As regards the occurrence of posterior pedicellariae in the exceptional cultures $P$. mil. o $\times$ E. esc. ô, there is no information in the papers.

In view of the uncertainty concerning the posterior pedicellaria in I9I2, I wrote to Dr Shearer for further information, and he kindly gave me the following particulars. As the records from 1912 were not available, Dr Shearer could not answer definitely for each combination, but said that some hybrids in I9I2 had a posterior pedicellaria although they did not go through metamorphosis, their development being very slow and irregular. Even if this

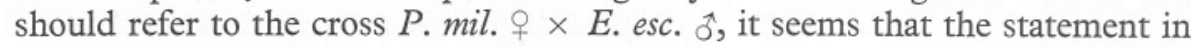
the last sentence of the three authors' paper, quoted above-that the posterior 
pedicellaria was definitely dominant in I9I2-must be a slip, as evidently most hybrids did not develop this organ. In his letter Dr Shearer mentions a fact of great interest. In a cross with one lot of $P$. miliaris fertilized eggs with $E$. esculentus sperms about $7 \%$ of the larvae developed a posterior pedicellaria, but neither green pigment nor posterior epaulettes. Thus we here meet with a new combination, $00+$. The reason why these larvae were not mentioned in the paper was that they did not develop in a normal way, as they did not produce proper Echinus rudiments. They were therefore considered as nonviable. Moreover, many of these posterior pedicellariae were not complete, as parts of the organ, e.g. one jaw, would sometimes be missing. Although the larvae of the type $00+$ thus were not quite normal, and the posterior pedicellaria was often malformed, we add this combination to the exceptions in our table.

The change of inheritance in I9I2 was thus as follows. In the majority of the crosses of $P$. miliaris $q$ with $E$. esculentus or $E$. acutus ${ }^{t}$ the inheritance was opposite to that of previous years, being paternal $(\mathrm{O}+)$ in I9I2 instead of maternal $(+0)$ in I909-II. Only in one culture, $P$. mil. ㅇ $\times$ E. esc. ô I9I2, some of the larvae inherited both characters from the female parent $(+0)$. In I9I2 there was, moreover, another type of exception, which occurred three times, in three different crosses: E. esc. $ᄋ \times P$. mil. $\hat{\jmath}$, E. acutus ㅇ $\times$ P. mil. $\hat{\sigma}$, and $P$. mil. $+\times E$. esc. $\hat{\delta}$. With lack of green pigment was combined the lack of one (OI) or of both (Oo) posterior epaulettes. Shearer, de Morgan \& Fuchs point out (I9I4, p. 308) that this shows that the two characters pigment and posterior epaulettes are not necessarily bound to be inherited in a special combination from the same parent, although this happens in the majority of larvae $(+0$ or $\mathrm{O}+)$. For some individuals $(00)$ inherited the absence of green pigment from one parent ( $(+$ or $\delta$ ) and the absence of the posterior epaulettes from the other ( $\hat{\sigma}$ or + ). "The characters are thus of the nature of unit characters and independent of one another." The larvae with only one posterior epaulette were called mosaic hybrids. Finally, in one lot of $P$. mil. $+\times E$. esc. $\widehat{t}$ hybrids a posterior pedicellaria could (according to private information) be formed in a few larvae lacking both green pigment and posterior epaulettes $(0 \circ+)$; but these larvae were rather abnormal and were therefore not mentioned in the papers.

In I9I4 some of the hybrids raised by Shearer, de Morgan \& Fuchs in the year I9I2 became sexually mature, but only those of the cross $E$. esc. 우 $\times E$. acutus. $\delta$. Unfortunately the $F_{2}$ generation of this cross afforded no information as to inheritance of the late larval characters, since the latter are alike in the two species. For that reason it was to be expected that a cross between this $E$. esculentus-acutus hybrid and pure $P$. miliaris would give the same result as when $P$. miliaris is crossed with either $E$. esculentus or $E$. acutus. Fuchs (I9I4) succeeded in rearing the larvae of both the reciprocal crosses, $E$. esc.-acutus $ᄋ \times P$. mil. $\delta$ and $P$. mil. $q \times$ E. esc.-acutus $\delta$. The inheritance of the larval characters was the same as in the hybrids of the pure species in 
I9I2: thus the $E$. esculentus or $E$. acutus characters dominated over those of $P$. miliaris in both reciprocal crosses $(0+$ in table). The general shape of the larvae is not described, nor is the posterior pedicellaria mentioned. This author has kindly told me in a letter that he cannot give any further information on this point, as he has no pre-war records left.

When I arrived at Plymouth at the end of May 1932, most of the E. esculentus obtained had already shed their sexual products. It was, however, possible to make a few fertilizations. A culture of E. esc. 우 $\times$ E. esc. ox exhibited, in the late larval stage, the normal features: no green pigment but posterior epaulettes and a posterior pedicellaria. Likewise pure $P$. miliaris larvae were of the normal type $(+\infty)$. The cross E. esc. 우 $\times$ P. mil. ot never reached later stages, but the hybrids $P$. mil. o $\times$ E. esc. ot showed a good development. Of the latter cross two fertilizations were made. The $P$. miliaris females used were rather different.

Lindahl \& Runnström (1929) have studied the variation of $P$. miliaris at different localities. They describe two types from the Swedish coasts. The $Z$-type belongs to more shallow water. These sea urchins cannot stand a high salinity. They grow considerably larger than those at greater depths. Their colour is mostly olive green, with violet spine-points. The sea urchins of the $S$-type are much smaller, their spines comparatively longer, their colour lighter, greyish yellowish to brownish and reddish, their spines also with violet points. They live in water of a higher salinity than those of the $Z$-type, although they seem not to be too well adapted. The gonads of the $S$-type are comparatively larger than those of the $Z$-type, and the eggs of the former are larger than those of the latter. Lindahl \& Runnström believe that these two types are only phenotypically different. For further information as to variation in size, shape and colour, distribution, sexual periods, influence of temperature, salinity, light, differences in habits, etc., I refer to the paper by Lindahl \& Runnström (1929).

These two authors studied material from several European localities, among others from Plymouth. Dr J. H. Orton had told them that besides the larger $P$. miliaris collected at low tide small specimens were dredged from greater depths. When Lindahl \& Runnström (I929, p. 42I) received material from the Eddystone grounds they found these small sea urchins surprisingly like the $S$-type from the deeper waters of Sweden, while, on the other hand, the animals from shallow waters in both countries also showed great similarities.

One of the fertilizations $P$. mil. . $\times$ E. esc. $\delta^{-1}$ in 1932 was made with the large eggs of a small, light-coloured $P$. miliaris from Eddystone, thus of a sea urchin closely resembling the $S$-type. We may call this culture the $S$-culture. For the other fertilization a large, olive green $P$ s. mil. , of the $Z$-type, was used. This animal had, however, not been recently brought in, but had lived for some time in an aquarium. This culture will be mentioned as the $Z$ culture. The larvae were put in plunger jars with outside sea water. They were 
examined at intervals individually, and some were reared through metamorphosis. Others were preserved at a late larval stage, and from these the drawings have been made. The young metamorphosed sea urchins were not reared.

The larvae of the $S$-culture grew larger than those of the $Z$-culture (cf. Figs. I, 2, with 3-6). The body is broad and the posterior end rather rounded, as in P. miliaris. The arms, however, are long and divergent as in E. esculentus. Just as the species characters are mixed in regard to the shape of the body and arms, so also the more definite late larval features are combined in an unusual way. Twenty-six plutei showed the paternal absence of green pigment and

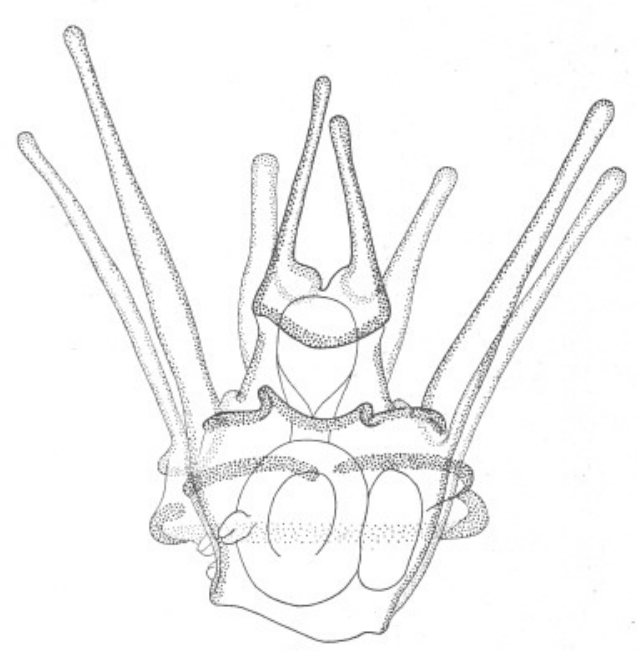

Fig. I.

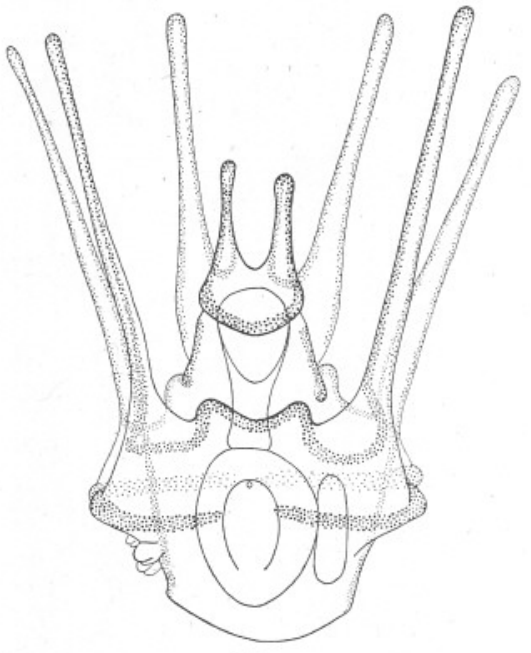

Fig. 2.

Figs. I and 2. Hybrids of Psammechinus miliaris $q$ from Eddystone (so-called $S$-type) $\times$ Echinus esculentus $\hat{0}$. Fertilization May 27, preserved July I, I932.

maternal absence of posterior epaulettes and posterior pedicellaria (0o0). It might be said that this lack of all the three larval characters is due to bad condition of the larvae. This can, however, hardly be true. The plutei were very uniform, regular in shape and had a normal Echinus rudiment, as seen from Figs. I and 2. One pluteus developed differently, having a posterior pedicellaria, thus $00+$ (small type in the table).

The $Z$-culture numbered forty-six larvae. They were not as uniform in shape as those of the $S$-culture. I have not records of all larvae in this respect, only of those preserved. Many of them have a rather high and narrow, square body like an E. esculentus. (Figs. 3-5). In spite of the absence of the posterior epaulettes, its posterior end is not rounded as in $P$. miliaris. If these features point towards E. esculentus, the arms are, however, not as divergent as in this species, but they are, on the other hand, comparatively longer than 
those of Ps. miliaris. Then there are some intermediate types leading to plutei of a pronounced P. miliaris type (Fig. 6). In these larvae the body is broad and its posterior part more domed. The arms are comparatively short, although some of them may be longer than is general in pure P. miliaris plutei. As regards the body shape, the larvae in the $Z$-culture are thus less uniform than

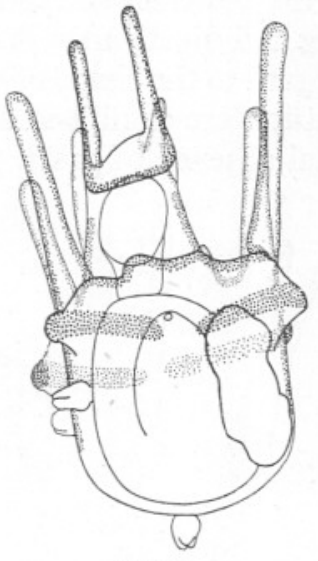

Fig. 3 .

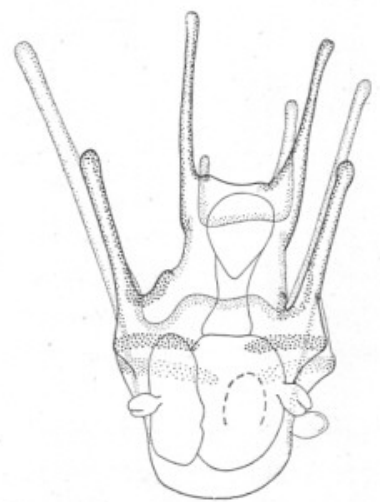

Fig. 5 .

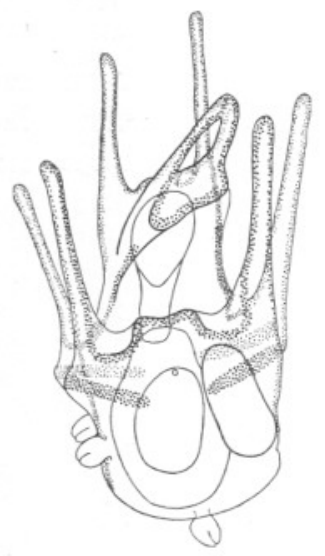

Fig. 4

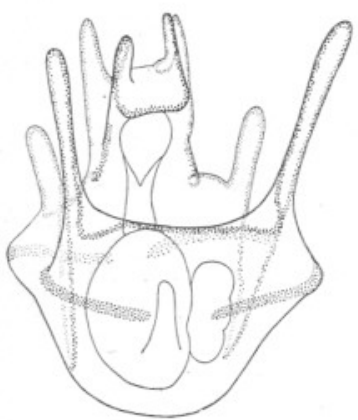

Fig. 6.

Figs. 3-6. Hybrids of Psammechinus miliaris of from the shore $(Z$-type $) \times$ Echinus esculentus 0 . Fertilized June 6, preserved July 20 I932.

those of the $S$-culture. Some more resemble the male, some the female parent. But in both cultures the features are more or less mixed. If we now turn to the three characters dealt with in our table, we find thirty-one plutei devoid of all of them (0o0, Figs. 5, 6), as the great majority in the $S$-culture. But ten larvae possessed a well-developed posterior pedicellaria ( $00+$, Figs. $3,4)$. Only four of these are in the preserved material. In those four larvae the posterior pedicellaria is combined with an E. esculentus-like body. Whether 
this was so in the other six larvae I do not know. Finally, in five plutei there was a small pigmented protrusion in place of a posterior pedicellaria. One larva is peculiar in having-beside two pedicellariae on the right side -a pedicellaria also on the left side, although the Echinus rudiment is well developed (Fig. 5).

These results are interesting in several respects. We have mentioned above that the $S$ - and $Z$-forms of $P$. miliaris are different in regard to both external characters and habits, but that the differences have been considered to be only of a phenotypical nature (p. I04). Nevertheless, we find a marked difference between the hybrids from $S$ eggs and those from $Z$ eggs. The former are large and of a uniform type (Figs, I, 2), the latter look smaller and have the $E$. esculentus and Ps. miliaris characters mixed in different ways in different individuals, but none has the general appearance of the $Z$ larvae (cf. Figs. I, 2 with Figs. 3-6).

In 1932 the combinations of the characters green pigment, posterior epaulettes, and posterior pedicellaria, were neither those of I909-I I, nor those of the most common type of I9I2 or I9I4. Our most frequent type in I932 was ०००, which type occurred only as the exception in three cultures of I9I2, and we recall that it then appeared in the three different crosses $E$. esc. $ᄋ \times P$. mil. $\widehat{\sigma}$, E. acutus $q \times P$. mil. $\hat{\sigma}$, and P. mil. $q \times$ E. esc. $\hat{\sigma}$. But the larvae in these exceptional cultures did not develop in a very normal manner. This rather universal combination (000) was thus dominant in 1932 , both with the $S$ eggs (twenty-six larvae) and the $Z$ eggs (thirty-one larvae). It would seem from the three exceptional cultures in I9I2, in which the larvae were not particularly healthy, that the lack of all three of these larval characters might be just a sign of a bad condition of the larvae. But I do not think that it necessarily is so. As seen from the drawings, our larvae were in good condition, and many of these 000 larvae went through metamorphosis. The development of a posterior pedicellaria in some of the larvae without both green pigment and posterior epaulettes $(00+)$ represents a new type, hitherto not mentioned in the literature and only known through Dr Shearer's kind information. In our cultures the larvae were perfectly healthy, and the posterior pedicellaria well developed, while the 00 + larvae from I9I 2 were evidently very irregular (cf. above). Thus the two combinations of 1932,000 and $00+$, in I9I2 appeared only as exceptions and in rather abnormal larvae, but in 1932 they represented the only types and the larvae were in excellent condition. It thus seems to me that in the larvae of 1932 there was a different combination of factors expressing themselves from that in the healthy hybrids of previous years.

To summarize, the crosses with $P$. miliaris eggs in I909-II invariably gave $+\infty$, in I9I2 and I9I4 mostly $0+0$, but some not very healthy larvae showed the exceptions +0 ?, oI?, 000 or $00+$. In I932, 000 and $00+$ were the rule. What can have caused these changes in inheritance? Shearer, de Morgan \& Fuchs (I9I4) suggest that the change of inheritance in I9I2 must have been 
due to some factor affecting the eggs of $P$. miliaris during their growth and maturation, as the same change was found whether sperms of E. esculentus or of $E$. acutus were used. The three authors found that the cause was not the relative ripeness of the eggs, as crossing at the beginning, middle, and end of the breeding period of each species gave no difference in inheritance. They further point out that the change was not due to changed conditions at, or after, fertilization, as changed alkalinity of the sea water and different laboratory temperatures had no influence. That the general physiological condition of the P. miliaris eggs was different in $19 \mathrm{I} 2$ is indicated, according to the same authors, by the ill-health of pure cultures of this species, and by the low percentages of fertilization in crossing with $P$. miliaris + that year. An investigation of the cytology of the crosses established that a true fusion of male and female pronuclei invariably took place. As to a possible elimination of chromosomes in the segmentation stages, Shearer, de Morgan \& Fuchs did not succeed in correlating the character of inheritance with such eliminations. They suggest that the peculiar temperature conditions of the sea water at Plymouth in the season I9II-I2 may have played a part in bringing about the change in inheritance.

If we compare the temperature data given by Shearer, de Morgan \& Fuchs (I9I4, text-fig. I7), the curve for I9I2 shows a lower temperature than those of 1909 and I9Io in the middle of February, but a higher temperature in April and May. The difference is hardly more than $\mathrm{I}^{\circ} \mathrm{C}$. On the other hand, the curve for I9II is decidedly lower than that for I909. It seems to me that the difference in heat from January to June is greater between the years I909 and I9II than between I909 and I9I2. At Naples Paracentrotus lividus has a breeding season extending over the whole year, i.e. each individual is probably ripe several times each year, both winter and summer. The winter temperature of the Mediterranean at Naples is $13^{\circ} \mathrm{C}$., the summer temperature $26^{\circ} \mathrm{C}$. The eggs taken out of an animal in the winter cannot deyelop normally at the summer temperature, and vice versa (Hörstadius, 1925). But the animals adapt themselves and their eggs to this considerable change of $13^{\circ}$ in a few months. I can hardly believe that the small differences in temperature to which Shearer, de Morgan \& Fuchs refer can be such as to affect the eggs of $P$. miliaris in any considerable way, the more so as the temperature during the following part of the breeding period (to October or November) is normally still higher than in May and June I9I2, as the sea water in the summer reaches a temperature of about $16^{\circ} \mathrm{C}$., while the curves given only reach about $13^{\circ} \mathrm{C}$. at the beginning of June.

In I9I4 Fuchs (I9I4) obtained the same inheritance as in I9I2. He used hybrids E. esc. + + $\times$ E. acutus $\widehat{\delta}^{\hat{t}}$ as one parent, but this difference ought not to be of great importance, for these two species have the same characters and the crosses $P$. miliaris eggs with either E. esculentus or $E$. acutus sperms gave the same result in I909-II and I9I2 respectively. If the temperature conditions in 1912 were the cause of the change in inheritance that year, we ought to have 
had the same temperature variations in I9I4, as the results of the crosses were the same as in I9I2. Mr F. S. Russell, of the Plymouth Laboratory, has kindly provided me with the corresponding weekly temperatures at the end of the Promenade Pier in the year I9I4 (from the Plymouth Meteorological Observatory). If these data (given below) are plotted on Shearer, de Morgan \& Fuchs text-fig. I 7 we find that the curve for I9I4, up to the middle of February, is practically identical with that of I9Io. From the middle of February onwards (to about June I) the curve of I9I4 is nearest to that of I909, but on the whole shows about $0.7^{\circ} \mathrm{F}$. $\left(0.5^{\circ} \mathrm{C}\right.$.) a higher temperature than that year. It lies between the curves of 1909 and I9I2, and is therefore the one that during these months most closely resembles that of I9I2. The temperatures in I9I4 thus do not show the extremes of I9I2, neither the particularly low temperature in February, nor the high temperature in the spring, but, on the other hand, the curve of I9I4 is the one coming nearest to that of I9I2, being in a way intermediate between this one and those of I909-II.

\begin{tabular}{|c|c|c|c|}
\hline $\begin{array}{l}\text { Week } \\
\text { ending }\end{array}$ & $\underset{\mathrm{F} .}{\text { Temp. }}$ & $\begin{array}{c}\text { Week } \\
\text { ending }\end{array}$ & $\begin{array}{c}\text { Temp. } \\
\text { F. }\end{array}$ \\
\hline Jan. $\begin{array}{r}3 \\
10\end{array}$ & $\begin{array}{l}47.6 \\
48.0\end{array}$ & Mar. ${ }_{28}^{21}$ & $\begin{array}{l}47 \cdot 6 \\
48 \cdot 0\end{array}$ \\
\hline I7 & $46 \cdot 6$ & Apr. 4 & $50 \cdot 6$ \\
\hline 24 & $45 \cdot 3$ & II & $49 \cdot 5$ \\
\hline $3 i$ & 45.9 & I8 & $50 \cdot 7$ \\
\hline Feb. 7 & $47 \cdot 9$ & 25 & $52 \cdot 2$ \\
\hline I4 & 47.5 & May 2 & 53.0 \\
\hline $2 \mathrm{I}$ & $47 \cdot 2$ & 9 & $52 \cdot 8$ \\
\hline 28 & 47.0 & I6 & $53 \cdot 3$ \\
\hline Mar. 7 & $46 \cdot 7$ & 23 & 56.0 \\
\hline I4 & 48.0 & 30 & $54 \cdot 5$ \\
\hline
\end{tabular}

As our $Z$ female in 1932 had been kept for some time in the aquarium tanks, and as we do not know how long it had been living there, a comparison of the sea-water temperatures of 1932 with those of previous years is not of much value. However, it may be mentioned that in 1932 the temperature in January and February was much higher than in any of the years I909-I4, whereas in March-May it was lower than any other year except I9II. The conditions are thus the contrary of those of the extreme year I9I2.

Mr Russell has kindly sent me records of the bottom temperatures of E I, ten miles south-west of Eddystone. There are no records for the bottom temperature at the Eddystone (from where our $S$-type female had been taken), but it is likely to have been very similar to E I. The sea water at this depth is generally warmer in the winter and cooler in the spring and summer than at the Promenade Pier. In 1932 this tendency was still more obvious at E I. Here the temperatures were: Jan. I, II $25^{\circ} \mathrm{C}$.; Feb. II $00^{\circ}$; March, $8.9^{\circ}$; April, $8.5^{\circ}$; May, $9.0^{\circ}$, and June I, 9.6. The divergence from the mean of about ro years is, for the same months, as follows: Jan. $+0 \cdot 75^{\circ}, \mathrm{Feb} .+\mathrm{I} \cdot 40^{\circ}$, March $0^{\circ}$, April $-0.5^{\circ}$, May $-0.6^{\circ}$, and June $-0.7^{\circ} \mathrm{C}$. Thus 1932 was rather abnormal, being at first considerably warmer than normal and then colder, both at E I and the Promenade Pier. 
Although the curve for I9I4 is fairly similar to that of I9I2 and the same results were obtained for these two years $(\mathrm{O}+)$ it is not quite clear that the temperature is the direct cause of the change of inheritance. It seems to me that the differences in temperature are too small to be of any probable importance. Moreover, some of the exceptions in 1912, which, too, are considered to have been due to the temperature conditions, were the rule in 1932, when the $S$-type had been exposed to unusual temperatures, differing from the normal in an exactly opposite direction from those in I9I2 or I9I4. The same holds for the shore temperature, but this fact is not significant, as we do not know how many days the $Z$ female had been kept in the tank. Thus it is impossible to say anything with certainty as regards the possible role of the temperature.

In their description of the physical conditions of the sea water Shearer, de Morgan \& Fuchs (1914, p. 272) mention a fact of interest. While according to them the $p \mathrm{H}$ of the outside sea water is generally $8 \cdot 15-8.25$, the tests in the spring of I9I2 showed only about $7 \cdot 9$. The alkalinity is of great importance for the function of sexual products. Mortensen (1913) found that artificial fertilization was possible in Holothuria nigra only after the $p \mathrm{H}$ of the sea water had been raised, and this method has been widely used. To give another example, the maturation of the eggs in the annelid Pomatoceros triqueter is initiated when the eggs from the acid body fluid are shed in alkaline sea water (Hörstadius, 1923). The influence of $p \mathrm{H}$ on the mobility of sperms and maturation of eggs naturally does not indicate that a lower $p \mathrm{H}$ affects the sexual products during their development in the body, particularly as the inner milieu is probably rather stable even if slight external changes in $p \mathrm{H}$ occur. But this factor ought to be mentioned, as well as the small changes in temperature.

The fact that the hybridization of $P$. miliaris eggs gave the same change of inheritance in 1912, whether sperms of E. esculentus or E. acutus were used, does not necessarily prove that the change was due to some factor affecting the eggs of $P$. miliaris during the period of their growth and maturation. Environmental influences during the larval development are not excluded. Shearer, de Morgan \& Fuchs state that the change of inheritance was not due to varied conditions during or after fertilization, as changed alkalinity and different laboratory temperatures had no influence. But other factors are conceivable. The three authors used Berkefeld filtered "tank water" for rearing their larvae (19I4, p. 275). This means sea water taken from the supply circulating through the tanks of the aquarium. This water circulates for a considerable time. For this reason we must reckon with a greater or lesser amount of excretory products of all kinds in the water. To what extent such products accumulate, and how soon they break down we do not know; but it is possible that they occur in different concentrations at different times and may have some influence. Furthermore, the tank water in the Plymouth Aquarium is treated with lime $\left(\mathrm{Ca}(\mathrm{OH})_{2}\right)$ in order to replace the loss of calcium caused by the animals in the aquaria. For this reason tank water may vary in several 
respects at different times. Thus other factors than change of temperature and alkalinity may possibly have affected the eggs and larvae during development. And that the change of inheritance occurred with the use of $P$. miliaris eggs might be due to the $P$. miliaris eggs being particularly sensitive to environmental factors during development. However, it does not seem very probable that the cause of the change of inheritance is to be found in external factors during larval development.

A considerable literature deals with the variation of sea-urchin hybrid larvae. Many different species have been used, and usually only the skeleton has been studied. The results are very contradictory. For example, Herbst (I906b), Tennent (I9II), Loeb, King \& Moore (I9IO) ascribed differences in dominance to changes in alkalinity, while Koehler (I9I6) repudiated any influence of alkalinity. Herbst (I906a) thought the relative ripeness of the germ cells to be of no importance, but found the temperature during development to affect the type of the hybrid larvae, but there is also, according to Herbst, an inner factor to take into consideration. On the other hand, in I 898 Vernon attributed the differences in inheritance to seasonal differences in the ripeness of the germ cells; and so did Koehler (I9I6), who also expressly denied Herbst's statement that a higher temperature caused a development more similar to the mother. v. Ubisch (1932), and Nümann (1933) found an excess of skeletal elements when the temperature was raised. For a review of this vast literature, see Nümann (1933).

The only safe conclusion from all these investigations seems to be that the amount of skeleton produced is increased by higher temperature during larval development and that the skeletal characters in most sea-urchin larvae are not sufficiently definite to be relied upon. Furthermore, it seems highly probable that the type of inheritance depends upon an inner factor, the physiological condition of the germ cells, but we do not know whether this is a consequence of the age of the germ cells or of the season or of some factor other than the temperature influencing the animals during the development of their sexual products. Thus Nümann (1933) found both hybrid larvae of intermediate type and those resembling the mother at the same time in the season, only by using eggs of different females. Furthermore, it must be pointed out that eggs of different females, taken the same day from the same habitat-according to the experiences from developmental physiology — are often very different in their sensitiveness to different physiological agents, such as animalizing or vegetativizing substances, radiation, etc. (see Hörstadius, I935; Lindahl, I936; and others).

Shearer, de Morgan \& Fuchs realized that the skeletal characters were too variable to be reliable for an investigation of inheritance in hybrids of Psammechinus and Echinus. They therefore studied the presence or absence of other organs. In regard to the presence or absence of green pigment, posterior epaulettes, and posterior pedicellaria, too, we probably have to maintain the suggestion made by several previous authors (cf. above) that the differences 
are due to some unknown inner factor. The temperature may have played a part in affecting this factor, but it can hardly be the temperature alone that is responsible for the changes in inheritance reviewed in this paper: in 1912 four different combinations were found, and two of them returned in 1932, although the temperature of the sea was quite different. It would be of interest if, for a sequence of years, crosses of $P$. miliaris $S$-type and $Z$-type with $E$. esculentus and E. acutus could be further studied at Plymouth, and the results compared with the physical conditions of the sea water.

\section{SUMMARY}

In 1932 crosses were made at Plymouth between Psammechinus miliaris ${ }_{\text {, }}$ both $Z$-type (from the shore) and $S$-type (from Eddystone), and Echinus esculentus 0 . The larvae from the $S$ eggs differed in size and shape from those from the $Z$ eggs (cf. Figs. I, 2 with 3-6). None of the hybrid plutei possessed the green pigment of $P$. miliaris, nor the posterior epaulettes of $E$. esculentus. Some of the larvae (Figs. 3, 4) had a posterior pedicellaria, like E. esculentus, in others this organ was missing (Figs. I, 2, 5, 6). Some of these plutei were preserved, others went through metamorphosis. Healthy larvae of these combinations (00+ and 000$)$ have not hitherto been described. The results are compared with those of previous authors (see table, p. I00). Some possible causes of change of inheritance in different years are discussed.

\section{REFERENCES}

Fuchs, H. M., I914. On $F_{2}$ Echinus hybrids. Fourn. Mar. Biol. Assoc., Vol. x, pp. $464-5$.

Herbst, Curt, I906a. Vererbungsstudien I-III. Arch. Entw.-mech., Vol. 21, pp. I73-305.

—— I906b. Vererbungsstudien IV. Arch. Entw.-mech., Vol. 22, pp. 473-97.

Hörstadius, Sven, 1923. Physiologische Studien über die Eireifung bei Pomatoceros triqueter L. Arch. mikr. Anat. u. Entw.-mech., Vol. 98, pp. I-9.

—_ I925. Temperaturanpassung bei den Eiern von Paracentrotus lividus Lk. Biologia Generalis, Vol. I, pp. 522-36.

- I935. Úber die Determination im Verlaufe der Eiachse bei Seeigeln. Pubbl. Staz. Zool. Napoli, Vol. I4, pp. 25 I-479.

— I936. Studien über heterosperme Seeigelmerogone etc. Mém. Mus. R. d'Hist. Nat., Bruxelles, sér. 2, fasc. 3, pp. 80I-80.

KoEHLER, O., I9I6. Úber die Ursachen der Variabilität bei Gattungsbastarden von Echiniden. Zeitschr. ind. Abst. u. Vererb., Vol. I5.

LINDAHL, P. E., 1936. Zur Kenntnis der physiologischen Grundlagen der Determination im Seeigelkeim. Acta Zool., Vol. I7, pp. I79-365.

Lindahl, P. E., \& RunNströM, J., I929. Variation und Ökologie von Psammechinus miliaris (Gmelin). Acta Zool., Vol. Io, pp. 40I-84.

Loeb, Jacques, Redman KIng, W. O. \& Moore, A. R., I9Io. Über Dominanzerscheinungen bei den hybriden Pluteen des Seeigels. Arch. Entw.-mech., Vol. 29, pp. 354-62. 
Mortensen, Th., I9I3. On the development of some British Echinoderms. Fourn. Mar. Biol. Assoc., Vol. x, pp. I-I8.

NÜMANN, WILHELM, I933. Untersuchungen der Skelette an Varianten, Bastarden und Chimären von regulären und irregulären Seeigeln. Zeitschr. ind. Abst. u. Vererb., Vol. 65, pp. 447-522.

Shearer, Cr., Morgan, W. DE \& Fuchs, H. M., I9II. Preliminary notice on the experimental hybridization of Echinoids. Fourn. Mar. Biol. Assoc., Vol. Ix, pp. I 2 I-4I.

I912. On paternal characters in Echinoid hybrids. Quart. Fourn. Micr. Sci., Vol. 58, pp. 337-52.

I914. On the experimental hybridization of Echinoids. Phil. Trans. Roy. Soc. London, ser. B, Vol. 204, pp. 255-362.

Tennent, D. H., I9ir. Echinoderm hybridization. Papers Tortugas Lab., Vol. 3, pp. II7-52.

v. UBISCH, L., I932. Untersuchungen über Formbildung. III. Roux Arch. Entw.mech., Vol. I27, pp. 216-50.

VeRnoN, H. M., I898. The relations between the hybrid and parent forms of Echinoid larvae. Phil. Trans. Roy. Soc. London, ser. B, Vol. I90, pp. 465-529. 